\title{
Relationship between Entry Level, Attitude and Students' Performance in Mathematics in Public Secondary Schools in Kisumu East District, Kenya
}

\author{
Manoah Sylvia Awuor
}

\begin{abstract}
Mathematics is one of the core subjects in secondary school curriculum. Performance in the subject is crucial for students' admission to scientific and technological professions.However, there has been persistent poor performance in the subject particularly in Kisumu East District as revealed by the Kenya Certificate of Secondary Education examination results for the years 2006 to 2008 with mean scores of 3.2282, 3.3691 and 4.0660 respectively.This may deny students access to the competitive professions. Factors contributing to this poor performance have not been exhaustively studied. The purpose of this study was to examine the relationship between students' entry level, attitude towards mathematics and performance in mathematics. The studywas conducted in public secondary schools in Kisumu East District and employed correlation design in which the dependent variable was performance and independent variables were entry level and attitude. The study sample was 986 Form 4 students, representing $33 \%$ of the population. Data collection instruments were students Questionnaire(SQ) and Mathematics Test(MT).Quantitative data was analysed using descriptive statistics and inferential statistics. Regression analysis wasrun to determine the relationship between the dependent and independent variables. The findings established that the two independent variables had significant effect on performance in MT for both girls and boys. Based on the results it is advisable that performance of students at KCPE to be considered during intake to Form 1,girls' attitude towards mathematic content and boys' attitude towards methods of teaching should be enhanced by mathematics teachers.
\end{abstract}

Index Terms - Attitude, Entry level, Form 4 students, Mathematics curriculum,Performance.

\section{INTRODUCTION}

There is widespread interest in improving the level of mathematics performance in schools. Apart from the economic benefits of better preparing young people for the numeracy demands of modern work place and raising the overall skill levels of the work force, there are also social benefits tied to improving access for larger numbers of young people to post- school education and training opportunities and laying stronger foundation to skills for lifelong learning. The interest in raising levels of performance has led to a focus on identifying the range of factors that shape performance as well as understanding how these factors operate to limit or enhance the performance of students by gender.
In Kenya, while a small proportion of secondary schools continue to offer satisfying well- rounded education programmes, the majority of schools fall short of providing for the learning needs of their students. Poor academic performance in key subjects in the curriculum like Mathematics and Science at the Kenya Certificate of Secondary Education (KCSE) examinations has not been satisfactory for quite a long time [15]. Several reasons have been given to account for these variations in performance in mathematics. [12]states that the root cause of poor performance in Mathematics is that the teachers are poorly prepared. [17]also reported that the performance in key curriculum subjects like Mathematics and Sciences at KCSE examination has not been satisfactory for quite a long time. Smaller student enrolments, class sizes with adequate and quality teaching, learning materials and equipment in private schools have led to better results thus the link between the quality of schools, resources and examination results.The Third International Mathematics and Science Study (TIMSS) in Australia showed that students' background variables influence differences in achievement in Mathematics. These findings imply that several factors contribute to performance in Mathematics than have been identified.

According to [14], performance in Mathematics has been generally poor. [11] also decries the poor performance in Mathematics despite the fact that it is one of the key subjects expected to turn Kenya into an industrialized country by the year 2030.The same trend has been noted in Kisumu East District over the last three years as depicted in the KCSE results of 2006 with a mean score of 3.2282, while in 2007 it had a mean score of 3.3691 and in 2008 it had a mean score of 4.0660 showing some slight improvement though still below average (D.E.O. Kisumu East District, 2009). The analysed results are given in Table 1.

Table I: Kisumu East District KCSE Mathematics Mean score by year.

\begin{tabular}{ll}
\hline Year & Mean Score \\
\hline 2006 & 3.2282 \\
2007 & 3.3691 \\
2008 & 4.0660 \\
\hline
\end{tabular}

\section{Given the}

persistent poor performance, it was important to establish factors contributing to this. Of particular interest to the study was the influence of students' entry level, attitude towards Mathematics on performance with specific reference to content, objectives, methods and evaluation of mathematics curriculum in Public Secondary Schools in Kisumu East District. 
Therefore thespecific objectives of the study were to:

1. Determine students' performance in Mathematics Test across gender.

2. Establish students' entry level in mathematics across gender.

3. Establish students' attitude towards mathematics across gender with reference to:

i .Objectives

ii. Content

iii. Methods

iv. Evaluation

4. Determine relationship between performance and entry level, attitude towards Mathematics

\section{LITERATURE}

As the world moves towards a Mathematical economy in which those with numeric skills prosper, Kenyans continue to perform poorly at the subject. Performance in mathematics in national examination is perpetually dismal with average scores of below 25 percent in KCSE and below 50 percent in KCPE [1].The root cause of poor performance in Mathematics is that Mathematics teachers are poorly prepared [1]. Most mathematics teachers lack pedagogical skills. So while they are highly knowledgeable on the subject content, they are handicapped in delivery. The result is the discipline is made to look abstract that learners cannot relate to learning. Apart from teachers' lack of pedagogical skills, mastery of basic skills and concepts has always been recognized as an essential in the learning of Mathematics. Much of Mathematics learning is hierarchical in nature. Prerequisite need to be acquired before the more advanced and high-order skills can be learned. [4] mastery- learning strategy requires that students master simple tasks in a learning sequence before advancing to more difficult tasks. Bloom contends that a mastery of each preceding task in a hierarchical sequence equips students with the necessary prerequisites for, and hence facilitates the learning of subsequent tasks. The learning of Mathematics provides an ideal context in which such a notion can be empirically tested. The students registered in a school are an important input component and it is argued that higher achievers at lower levels have got innate ability to perform well in the succeeding levels.Mathematics is a science subject and some gender-based science researchers have reported that both the "feminists empiricists" and the "Liberal feminists critics" seem to agree is that females in principles will produce exactly the same scientific knowledge as males provided that sufficient rigor is under taken in scientific inquiry $[2 ; 5$; 16].The 2008 Kenya Universities Joint Admission Board Affirmative Action Report says poor performance in Mathematics limit their choice of course. More females end up in low-demand courses and their representation remains small in Science and Mathematics [1].Attitude towards mathematics has been considered an important factor in influencing participation and success in mathematics. [19]state that investigation into student mathematics attitude and perspective not only informs teachers, parents, and administrators about student's needs, but also serves as a catalyst for reform in mathematics education. Attitude largely determines what students learn and their willingness to learn. While positive attitudes towards Mathematics can be related to better performance and higher educational achievement, participation in activities related to these fields may also help to keep students interested in the fields of Mathematics. There is research evidence showing that students' high performance in mathematics is not necessarily positively associated with their attitudes about mathematics and mathematics learning. Results of Third International Mathematics and Science Study (TIMSS) revealed that while Japanese students outperformed students from many other countries in mathematics, they displayed relatively negative attitudes towards mathematics [9].

\section{RESEARCH METHODOLOGY}

The study was carried out in Kisumu East District in Kenya. The population of Form four students was 2960 out of which $986(33.3 \%$ ) was selected by simple random sampling and stratified random sampling technique was applied to draw the sample from provincial and district that is 3 Provincial schools and 12 District schools to cater for differences in their performance that result from differences in admissions at Form 1 . This comprised of 493 female students and 493 male students. Simple random sampling method was used to select students of Form 4 in the year 2010 in each sample school because of the large number of students in those classes. A total of 986 students participated in the study. To avoid bias the sample consisted of equal number of male and female students. The population was stratified into provincial and district schools therefore proportionate allocations to the sample was used depending on the different population strata sizes. Since the provincial schools in the population had a proportion of $40.88 \%$, a sample size of 403 which is $33 \%$ of the total population size of 1210 represented the provincial schools. In the population strata of the provincial schools, 134 boys were chosen from boy schools and 135 girls were chosen from girls' schools, and from the mixed school 67 girls and 67 boys were chosen. The population of the district schools which was 1750 had a proportion of $59.12 \%$ of the total population. Therefore a sample of 583 students was selected which is $33 \%$ of the total population size of 1750 . In order to prevent bias that comes from disproportionate allocation an almost equal number of boys (292) and girls (291) were selected in the sample size of 583 from the district schools. All the district schools in the population were mixed schools. 
Table II: Sample Frame (Schools stratified by type)

\begin{tabular}{lccccl}
\hline School type & $\begin{array}{c}\text { No. of schools } \\
(\mathbf{N})\end{array}$ & $\begin{array}{l}\text { Sample } \\
(\mathbf{s c h o o l s})\end{array}$ & $\begin{array}{l}\text { Respondents } \\
(\mathbf{N})\end{array}$ & No. Selected(n) & $\begin{array}{l}\text { Percentage } \\
(\boldsymbol{\%})\end{array}$ \\
\hline Provincial & 10 & 3 & 1210 & 403 & 33 \\
\hline District & 37 & 12 & 1750 & 583 & 33 \\
\hline
\end{tabular}

Table III: Distribution of Respondents by sex

\begin{tabular}{lcc}
\hline School type & Boys & Girls \\
\hline Provincial single sex school & 134 & 135 \\
Provincial mixed school & 67 & 67 \\
District mixed school & 292 & 291 \\
TOTAL & $\mathbf{4 9 3}$ & $\mathbf{4 9 3}$ \\
\hline
\end{tabular}

\section{Instruments of Data Collection}

Two tools were used. These were Mathematics Test (MT) and Students Questionnaire (SQ) for Form 4 students .The MT had paper one and paper two.The SQ had open ended questions and a five point Likert scale developed by the researcher which was used to establish students' attitude towards mathematics curriculum and also give information concerning students' entry marks at Kenya Certificate of Primary Education (KCPE) which was triangulated by using results from Principal teachers'offices in various schools. Students were expected to indicate their level of agreement with various statements which were constructed based on the four Mathematics Curriculum elements mainly objectives, content, methods and evaluation procedures. Students' level of agreement ranged from Strongly Agree (SA), Agree (A), Undecided (U), Disagree (D) and Strongly Disagree (SD). The attitude scale had a total of 40 statements, 10 for each of the four elements namely, objectives, content, methods and evaluation. During analysis the items were identified as belonging to the four elements and analyzed separately.

\section{Validity and Reliability of the Instruments}

The content validity of the MT was established by use of Table of Specification afterwhich threeexperts in the field of study in Maseno University were used to ascertain the face and content validity of MT and SQ on the topic of study for purposes of checking face validity. Kothari (2004) notes that validity is the extent to which a measuring instrument provides adequate coverage of the topic under study, if the measurement contain a representative sample, the content validity is good. Also a panel of persons can judge how well the measuring instrument meets the standard. The suggestions made by the experts were used to revise the instruments before collecting data. For SQ on attitude,[3] recommend Alpha formula for rating scales. The results of MT and SQ were established through test- retest and application of Pearson Product Moment Correlation coefficient reliability which yielded a correlation coefficient of 0.71 and 0.73 respectively. [8]recommend for a 0.7 and above threshold. The pilot study involved 5 schools (not part of the study sample) representing $10 \%$ of the total number of schoolsin Kisumu East District.

\section{Data Collection Procedures}

The researcher sought for a research permit from the National Council for Science and Technology inNairobi before embarking on data collection process as dictated by
ethics.The instruments wereadministered through personal visits on appointmentwith heads of mathematics departments in schools through the schools principals. The MT was administered in the presence of the researcher after agreeing on the dates. While the questionnaires were administered a day after MT was done.

\section{Data Analysis Procedure}

Data regarding students' entry level in mathematics across gender was obtained from students' questionnaire and confirmed by mathematics teachers records obtained from Document Analysis Guide. The data was analysed using descriptive statistics which produced mean, Standard Deviation (SD) and mean grade score.The results from MT and SQ filled by students provided data which was scrutinized and then coded for computer data analysis.Data on mathematics performance was first worked out as percentage and in form of grades i.e A, A-, B+, B, B-, C+, C, C-, D+, D, D-, and E. The highest grade was A while the lowest grade was E.The grades werecoded into their numerical equivalents i.e $12,11,10,9,8,7,6,5,4,3,2$, and 1 respectively from $A$ to $E$. While the percentage of each grade was as follows: A; 75 and above, A- ;(70 -74), B+;(65-69), B;(60-64), B-;(55-59), C+; (50-54), C; (45-49), C-;(40-44), D+;(35-39), D;(30-34), D-;(25-29), E;( 0-24).A researcher made scale copied from Kenya National Examination Council (KNEC) was used to rate the performance of students. A score from $70 \%$ up to $100 \%$ (grades A- to A) was considered as excellent, $55 \%$ up to $69 \%$ (grades B- up to B +) was considered as good, $40 \%$ up to $54 \%$ (grades $\mathrm{C}$ - up to $\mathrm{C}+$ ) was considered as average, $39 \%$ and below (grades D+ to E) was considered as below average and was rated as poor performance. Analysis of data concerning students' attitude in secondary school mathematics curriculum was done by calculating mean scores on the attitude scale. To achieve this, numerical scores were assigned to five options given to each item on the attitude scale. For positively stated items the score values were assigned as follows: Strongly Agreed(SA) -5; Agree(A)-4; Undecided (U)-3; Disagree (D) - 2; Strongly Disagree (SD)-1. However, for negatively stated items, the scoring was reversed as follows, Strongly Disagree(SD)-5; Disagree(D)-4; Undecided(U)-3; Agree (A)-2; Strongly Agree(SA)-1. The data was keyed into SPSS data editorfor analyses. Arithmetic mean was done for every element on the Likertscale, thereafter an average of the arithmetic means of the four elements on the Likert was done. In the interpretation of the scores, a value of between 2.5 and 3.4 meant a neutral 
attitude; on the other hand, a value between 3.5 and 5.0 meant a positive attitude while a value of between 2.4 and 1.0 meant a negative attitude.Therefore data on attitude was analyzed by using frequencies, means and percentages. Qualitative data was analyzed using responses to the open ended items in the questionnaire which were organized and reported in emergent themes. The data was presented in terms of tables. A one-way ANOVA was used to determine whether gender caused variationin performance at $95 \%$ confidence interval.A multiple regression analysis was run to produce a linear combination of independent variables (entry level, attitude) that would best predict the dependent variable that is performance in mathematics (MT).

\section{RESULTS AND DISCUSSION}

\section{Students' entry level across gender}

Results regarding students' entry level in Mathematics across gender was collected, analyzed and presented as shown in Table IV.

Table IV: Distribution of Mathematics grades at entry level (KCPE) by gender

\begin{tabular}{|c|c|c|c|c|}
\hline & Girls & & & \\
\hline $\begin{array}{l}\text { Mathematics } \\
\text { grade }\end{array}$ & Frequency & Percentage & Frequency & Percentage \\
\hline A & 80 & 16.23 & 86 & 17.44 \\
\hline A- & 68 & 13.79 & 82 & 16.63 \\
\hline B+ & 68 & 13.79 & 69 & 14.00 \\
\hline B & 77 & 15.62 & 83 & 16.84 \\
\hline B- & 51 & 10.34 & 46 & 9.33 \\
\hline $\mathrm{C}+$ & 77 & 15.62 & 71 & 14.40 \\
\hline $\mathrm{C}$ & 27 & 5.48 & 24 & 4.87 \\
\hline C- & 26 & 5.27 & 20 & 4.06 \\
\hline D+ & 14 & 2.84 & 8 & 1.62 \\
\hline D & 2 & 0.41 & 4 & 0.81 \\
\hline D- & 3 & 0.61 & 0 & 0.00 \\
\hline E & 0 & 0.00 & 0 & 0.00 \\
\hline Total & 493 & 100 & 493 & 100 \\
\hline
\end{tabular}

Mean score for Girls: 61.61\%, Standard Deviation-12.31, Mean grade score- 8.89

Mean score for Boys: 63.15\%, Standard Deviation-11.61,

Mean grade score-9.17

Overall mean score: $62.38 \%$, Standard Deviation-11.98, Mean grade score-9.04

The finding of students entry marks was as follows: The girls had a mean percentage of $61.61(\mathrm{SD}=12.31)$ with a mean grade score of 8.89 corresponding to a mean grade of $\mathrm{B}$ plain with a mean grade score of 9.17 corresponding to a mean grade of B plain .Overall entry performance of students was a mean percentage of 62.38 ( $\mathrm{SD}=11.98)$ with a mean grade score of 9.04 corresponding to a mean grade of B plain which was considered to be relatively high. From the analysis, it can be deduced that the students had acquired prerequisite skills needed in learning mathematics before the more advanced and higher order skills required in secondary mathematics could be learned.The results to performance of students in Mathematics Test ( MT) across gender was shown in Table V. while boys had a mean percentage score of $63.15(\mathrm{SD}=11.61)$

Table V: Distribution of Mathematics grades in MT by gender

\begin{tabular}{llllc}
\hline & \multicolumn{2}{c}{ Girls } & \multicolumn{2}{c}{ Boys } \\
\hline $\begin{array}{l}\text { Mathematics } \\
\text { grade }\end{array}$ & Frequency & Percentage & Frequency & Percentage \\
\hline A & 10 & 2.03 & 10 & 2.03 \\
A- & 8 & 1.62 & 11 & 2.23 \\
B+ & 20 & 4.06 & 18 & 3.65 \\
B & 24 & 4.87 & 26 & 5.27 \\
B- & 19 & 3.85 & 20 & 4.06 \\
C+ & 44 & 8.93 & 39 & 7.91 \\
C & 16 & 3.25 & 21 & 4.26 \\
C- & 32 & 6.49 & 32 & 6.49 \\
D+ & 21 & 4.26 & 22 & 4.46 \\
D & 42 & 8.52 & 63 & 12.78 \\
D- & 14.00 & 72 & 14.60 \\
E & 189 & 38.13 & 159 & 32.25 \\
Total & $\mathbf{4 9 3}$ & $\mathbf{1 0 0}$ & $\mathbf{4 9 3}$ & $\mathbf{1 0 0}$ \\
\hline
\end{tabular}

Overall mean score-34.86, $\mathrm{SD}=18.79$, Mean grade score-

Mean score for girls: 33.64, $\mathrm{SD}=18.24$, Mean grade 3.86, Mean grade- D+ score-3.20, Mean grade- D plain

Mean score for boys: $35.08, \mathrm{SD}=19.31$, Mean grade score3.86, Mean grade- D+

The finding of performance was as follows: The girls had a mean percentage of $33.64(\mathrm{SD}=18.24)$ with a mean score of 
3.20 corresponding to a mean grade of $\mathrm{D}$ plain while boys had a mean percentage of 35.08( $\mathrm{SD}=19.31)$ with a mean grade score of 3.86 corresponding to a mean grade of D+. Overall performance of the students was a mean percentage of 34.36 $(\mathrm{SD}=18.79)$ with a mean score of 3.80 corresponding to a mean grade of D+.From the analysis of MT, it can be deduced that performance has seriously dropped from a mean score of 9.04 at entry level to a mean score of 3.86 at MT.The result confirms the dismal performance in mathematics in national examination [1]. This high drop in performance may have been as a result of the negative/neutral attitude displayed by students in regard to methods and evaluation which are two out of the four elements of Mathematics curriculum. According to [12], the cause of poor performance in mathematics is as a result of mathematics teachers who make the subject appear abstract that learners cannot relate to learning. The teachers approach to mathematics content may also have affected the performance in MT.

Students Attitude towards Mathematics Curriculum across Gender
Students attitude towards mathematics was done with specific reference to thefour elements of Mathematics curriculum namely: Objectives, Content, Methods and Evaluation. On objectives both girls and boys had a mean score of 3.8 displaying a positive attitude. On content, girls had a mean score of 2.7 displaying a neutral attitude while boys had a mean score of 3.5 displaying a positive attitude. On methods girls had a mean score of 2.3 displaying a negative attitude while boys had a mean of score of 2.8 displaying a neutral attitude. Finally on evaluation, girls had a mean score of 2.4 displaying a negative attitude while boys had a mean of score of 2.7 displaying a neutral attitude. In general, girls attitude towards mathematics have a mean score of 2.8 displaying a neutral attitude while boys had a mean score of 3.2 displaying the same neutral attitude towards mathematics curriculum. This finding shows that students attitude towards the elements of Mathematics curriculum may have affected performance at MT. The analysis of students'attitude is given in Table VI.

Table VI: Attitude of girls and boys towards the elements of Mathematicscurriculum

\begin{tabular}{lllll}
\hline & \multicolumn{1}{c}{ Girls } & & Boys & \\
\hline Elements & Mean scores & Attitude & Mean scores & Attitude \\
\hline Objectives & 3.8 & Positive & 3.8 & Positive \\
Content & 2.7 & Neutral & 3.5 & Positive \\
Methods & 2.3 & Negative & 2.8 & Neutral \\
Evaluation & 2.4 & Negative & 2.7 & Neutral \\
Overall & $\mathbf{2 . 8}$ & Neutral & $\mathbf{3 . 2}$ & Neutral \\
\hline
\end{tabular}

The overall attitude of students towards mathematics was neutral. A study done by [18] revealed that rural and urban students attitude in mathematics positively affects their performance. It may be concluded from this study that students attitudeaffected their performance.

Relationship between performance and entry level, attitude towards mathematic

The objective of this study was to determine the relationship between dependent variable which is performance (MT) andindependent variables which are entry Table VII: Correlation Coefficients for girlsn $=493$

\begin{tabular}{lllllll}
\hline & $\mathbf{Y}_{1}$ & $\mathbf{X}_{\mathbf{1 1}}$ & $\mathbf{X}_{\mathbf{1 2}}$ & $\mathbf{X}_{\mathbf{1 3}}$ & $\mathbf{X}_{\mathbf{1 4}}$ & $\mathbf{X}_{\mathbf{1 5}}$ \\
\hline $\mathrm{Y}_{1}$ Pearson Correlation & 1.000 & & & & & \\
$\mathrm{X}_{11}$ Pearson Correlation & $.641^{* *}$ & 1.000 & & & &. \\
$\mathrm{X}_{12}$ Pearson Correlation & $.127^{*}$ & $.105^{* *}$ & 1.000 &. & & \\
$\mathrm{X}_{13}$ Pearson Correlation & $.319^{* *}$ & $.312^{* *}$ & $.293^{*}$ & 1.000 & & \\
$\mathrm{X}_{14}$ Pearson Correlation & $.189^{* *}$ & $.208^{* *}$ & $.184^{* *}$ & $.316^{* *}$ & 1.000 & .000 \\
$\mathrm{X}_{15}$ Pearson Correlation & $.206^{* *}$ & $.171^{* *}$ & $.093^{* *}$ & $.274^{* *}$ & $.193 * *$ & 1.000 \\
\hline
\end{tabular}

** Correlation is significant at the 0.01 level (2-tailed)

*Correlation is significant at the 0.05 level (2-tailed)

Key

$\mathrm{Y}_{1}=$ Performance in Mathematics Test (MT)

$\mathrm{X}_{11}=$ Performance in mathematics at KCPE

$\mathrm{X}_{12}=$ Attitude towards Objectives of mathematics curriculum

$\mathrm{X}_{13}=$ Attitude towards Content of mathematics curriculum

$\mathrm{X}_{14}=$ Attitude towards Methods of teaching mathematics

level and attitude towards mathematics curriculum across gender.To achieve this, firsttheresearcher correlated the dependent and independent variables.Pearson Product Moment Correlation was used to establish the strength and direction of the relationshipthat existed between the three variables. It gave rise to the following correlation matrices between the dependent variable and independent variables. Table VII and Table VIIIshows the correlation matrices for girls and boys respectively. curriculum

$\mathrm{X}_{15}=$ Attitude towards Evaluation of mathematics curriculum The correlation analysis for girls was $\mathrm{X}_{11}, \mathrm{r}=.641 ; \mathrm{X}_{12}, \mathrm{r}$ $=.127 ; \mathrm{X}_{13} ; \mathrm{r}=.319 ; \mathrm{X}_{14}, \mathrm{r}=.189 ; \mathrm{X}_{15}, \mathrm{r}=.206$

It is worth noting that all the independent variables were significantly associated with MT at 0.01 level (2-tailed) except for variable $\left(\mathrm{X}_{12}\right)$ which was significantly associated with MT at 0.05 level (2-tailed). 
Relationship between Entry Level, Attitude and Students' Performance in Mathematics in Public Secondary Schools in Kisumu East District, Kenya

Table VIII: Correlation Coefficients for boys

\begin{tabular}{|c|c|c|c|c|c|c|c|}
\hline & & $\mathrm{Y}_{2}$ & $X_{21}$ & $X_{22}$ & $\mathrm{X}_{23}$ & $X_{24}$ & $\mathrm{X}_{25}$ \\
\hline $\mathrm{Y}_{2}$ & Pearson Correlation & 1.000 & & & & & \\
\hline $\mathrm{X}_{21}$ & Pearson Correlation & $.547 * *$ & 1.000 & & & & \\
\hline $\mathrm{X}_{22}$ & Pearson Correlation & -.014 & .024 & 1.000 & & & \\
\hline $\mathrm{X}_{23}$ & Pearson Correlation & $.291 * *$ & $.364 * *$ & $.270 * *$ & 1.000 & & \\
\hline $\mathrm{X}_{24}$ & Pearson Correlation & $.195 * *$ & $.154 *$ & $266^{* *}$ & ${ }_{*} .385^{*}$ & 1.000 & . \\
\hline $\mathrm{X}_{25}$ & Pearson Correlation & $.145^{*}$ & $.133^{*}$ & $.195 * *$ & ${ }_{*}^{.248 *}$ & $.182 * *$ & 1.000 \\
\hline
\end{tabular}

** Correlation is significant at the 0.01 level (2-tailed).

*Correlation is significant at 0.05 level (2-tailed)

Key

$\mathrm{Y}_{2}=$ Performance in Mathematics Test (MT)

$\mathrm{X}_{21}=$ Performance in mathematics at KCSE

$\mathrm{X}_{22}=$ Attitude towards Objectives of mathematics curriculum

$\mathrm{X}_{23}=$ Attitude towards Content of mathematics curriculum

$\mathrm{X}_{24}=$ Attitude towards Methods used in teaching mathematics

$\mathrm{X}_{25}=$ Attitude towards Evaluation of mathematics curriculum

$\mathrm{X}_{21}, \mathrm{r}=.547 ; \mathrm{X}_{22}, \mathrm{r}=-.014 ; \mathrm{X}_{23} ; \mathrm{r}=.291 ; \mathrm{X}_{24}, \mathrm{r}=.195 ; \mathrm{X}_{25}, \mathrm{r}=.145$

It is worth noting that all the independent variables had significant association with dependent variable except Objectives of mathematics curriculum(X22) which was insignificant.

The study determined again the relationship between dependent variable and independent variables by running a multiple regression analysis for girls and boys respectively which produced Coefficient of Multiple Determination as shown in Table IX and Table X respectively.

TableIX:The Coefficient of Multiple Determination

\begin{tabular}{llll}
\hline $\mathrm{R}$ & $\mathrm{R}$ Square & $\begin{array}{l}\text { Adjusted } \mathrm{R} \\
\text { Square }\end{array}$ & Std. Error of the Estimate \\
\hline .653 & .426 & .421 & 14.873 \\
\hline
\end{tabular}

TableX: The Coefficient of Multiple Determination

\begin{tabular}{llll}
\hline $\mathrm{R}$ & $\mathrm{R}$ Square & $\begin{array}{l}\text { Adjusted } \\
\mathrm{R} \text { Square }\end{array}$ & Std. Error of the Estimate \\
\hline .558 & .312 & .306 & 15.410 \\
\hline
\end{tabular}

The correlation between the dependent variable (MT) and independent variables was 0.653 and

0.558 for girls and boys respectively.The model for the girls reveals that entry level and attitude towards mathematics curriculum explain $42.1 \%$ of the change in the dependent variable whilethe model for boys explain $30.6 \%$ of the variation in performance in mathematics curriculumas signified by the Adjusted $\mathrm{R}^{2}$.

When linear regression was used to analyze quantitative data for girls in the study,

The regression equation was specified as

$\mathrm{Y}_{1}=\mathrm{b}_{0}+\mathrm{b}_{1} \mathrm{X}_{11}+\mathrm{b}_{2} \mathrm{X}_{12}+\mathrm{b}_{3} \mathrm{X}_{13}+\mathrm{b}_{4} \mathrm{X}_{14}+\mathrm{b}_{5} \mathrm{X}_{15}+$ $\varepsilon_{1} \ldots \ldots \ldots \ldots \ldots \ldots \ldots \ldots \ldots$ (1)

Where, $b_{0}$ is the intercept

$\mathrm{X}_{11}$ Performance in Mathematics at Entry level (KCPE)

$\mathrm{X}_{12} \quad$ Attitude towards Objectives of mathematics curriculum

$\mathrm{X}_{13} \quad$ Attitude towards Content of the Mathematics Curriculum

$\mathrm{X}_{14}$ Attitude towards Methods used in teaching Mathematics Curriculum

$\mathrm{X}_{15}$ Attitude towards Evaluation used in Mathematics Curriculum

$\varepsilon_{1}$ is the error term of the regression equation

When regression was run and stepwise method was used to drop variables which were not importantin the model, the coefficients of important variable for girls is as shown in Table XI.

$b_{1}, b_{2}, \ldots \ldots b_{5}$ are respective regression coefficients for $\mathrm{X}_{11}, \mathrm{X}_{12}, \ldots \mathrm{X}_{15}$

$\mathrm{Y}_{1}$ Performance in Mathematics Test (MT)

Table XI: Regression Coefficient for girls

\begin{tabular}{|c|c|c|c|c|c|c|c|}
\hline & \multirow{2}{*}{\multicolumn{2}{|c|}{ Unstandardized Coefficients }} & \multirow{3}{*}{$\begin{array}{l}\text { Standardized } \\
\text { Coefficients } \\
\text { Beta } \\
\end{array}$} & \multirow{3}{*}{$\mathrm{t}$} & \multirow{3}{*}{ Sig. } & \multicolumn{2}{|c|}{ Colinearity Statistics } \\
\hline & & & & & & \multirow{2}{*}{ Tolerance } & \multirow{2}{*}{ VIF } \\
\hline & $\mathrm{B}$ & Std.Error & & & & & \\
\hline (Constant) & -44.406 & 7.222 & & -6.149 & $-.000^{*}$ & & \\
\hline $\mathrm{X}_{11}$ & .976 & .083 & .600 & 11.700 & $.000 *$ & .902 & 1.004 \\
\hline $\mathrm{X}_{13}$ & . 478 & 187 & .131 & 2.560 & .011 & .902 & 1.108 \\
\hline
\end{tabular}


Key

$\mathrm{X} 11=$ Performance at entry level

X13= Attitude towards content of mathematics Curriculum.

The coefficient of the estimated regression model in the regression analysis are represented by the unstandardized coefficients. The results suggest that out of the five independent variables only two of the independent variables were significantas shown byregression coefficients. These variables were performance at entry level (X11) and content of the mathematics curriculum (X13). Female students attitude towards objectives of mathematics curriculum ( $\mathrm{X} 12$ ), methods used in teaching mathematics (X14) and evaluation of themathematics curriculum (X15)were dropped

by the stepwise method indicating that they were not important in the relationship. The linear regression model is shown below as:

$$
\mathrm{Y} 1=-44.406+0.976 \times 11+0.478 \times 13
$$

The significance of the model was demonstrated in the $\mathrm{p}$-value of the analysis of variance of the regression model in Table XIIwhich had a p-value of 0.000 indicating that the two variables had significant effect on the dependent variable (MT).

Table XII: ANOVA Table for Multiple Regression Model

\begin{tabular}{llrlll}
\hline & Sumof & & Mean & \\
& Squares & df & Square & F & Sig. \\
\hline Regression & 39746.424 & 5 & 19873.212 & 89.836 & $.000(\mathrm{a})$ \\
Residual & 53534.458 & 487 & 221.217 & & \\
Total & 93280.882 & 492 & & & \\
\hline
\end{tabular}

a Predictors: (Constant), $\mathrm{X}_{11}, \mathrm{X}_{13}$

Dependent Variable: MT

From theregression coefficients it was concluded that girls can perform better in KCSE examination if their entry level could be considered during intake for admission to Form 1, and also if their attitude towards content of mathematics could be changed by making them participate in activities related to the field of mathematics like Science, Mathematics and Technology(SMT) camps, SMT clubs [13].

Regression coefficients for boys

When linear regression was used to analyze quantitative data in the study,

The regression equation was specified as

$\mathrm{Y} 2=\mathrm{b} 0+\mathrm{b} 1 \mathrm{X} 21+\mathrm{b} 2 \mathrm{X} 22+\mathrm{b} 3 \mathrm{X} 23+\mathrm{b} 4 \mathrm{X} 24+\mathrm{b} 5 \mathrm{X} 25+$

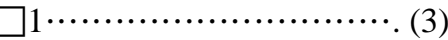

Where, bois the intercept b1, b2, .....b5are respective regression coefficients for Table XIII

Table XIII:Regression Coefficient for boys

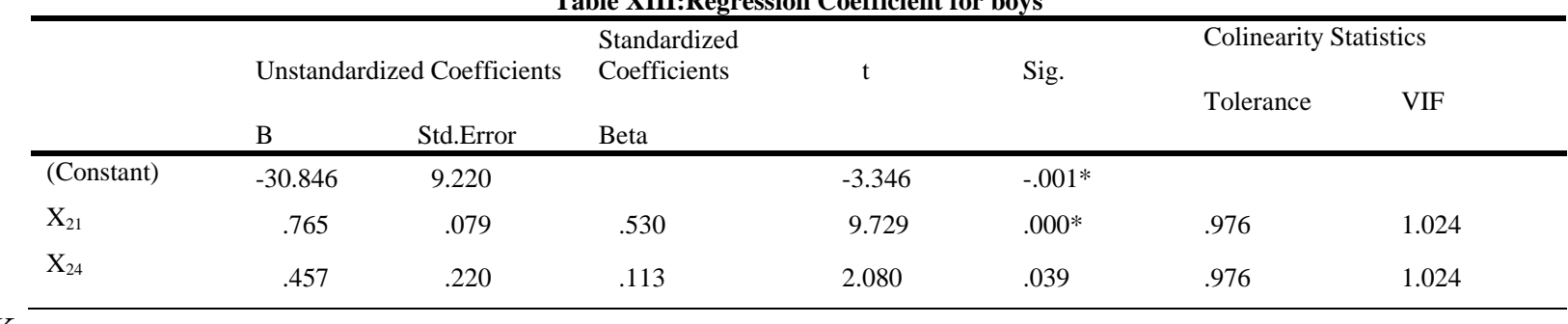

Key

X21 = Performance at entry level (KCPE)

X24 = Attitude towards methods used in teaching Mathematics

The coefficient of the estimated regression model in the regression analysis are represented by the unstandardized coefficients. The results suggest that out of the five independent variables only two of the independent variables were significant as shown by regression coefficients. These variables were performance at entry level (X21) andattitude towards methods of teaching mathematics (X24). Male students attitude towards objectives used in teaching mathematics curriculum ( X22), attitude towards content of
$\mathrm{X} 21, \mathrm{X} 22, \ldots \mathrm{X} 25$

Y2Performance in Mathematics Test (MT)

$\mathrm{X} 21$ Performance in Mathematics at Entry level (KCPE)

X22Attitude towards Objectives of mathematics curriculum

X23 Attitude towards Content of the Mathematics Curriculum

X24 Attitude towards Methods used in teaching Mathematics Curriculum

X25Attitude towards Evaluation used in Mathematics Curriculum

$\square 2$ is the error term of the regression equation

When regression was run and stepwise method was used to drop variables which were not important in the model, the coefficients of important variable for boys is as shown in

mathematics curriculum(X23) and attitude towards evaluation of the mathematics curriculum (X25) were dropped by the stepwise method indicating that they were not important in the relationship. The linear regression model is shown below as:

$$
\mathrm{Y} 2=-30.846+0.765 \mathrm{X} 21+0.457 \mathrm{X} 24
$$

The significance of the model was demonstrated in the 
Relationship between Entry Level, Attitude and Students' Performance in Mathematics in Public Secondary Schools in Kisumu East District, Kenya

p-value of the analysis of variance of the regression model in

Table XIVwhich had a p-value of 0.000 indicating that the Table XIV: ANOVA Table for the Multiple Regression Model two variables had significant effect on the dependent variable (MT).

\begin{tabular}{llccc} 
& Sum of Squares & df & Mean Square & F \\
\hline Regression & 25559.399 & 5 & 12799.699 & 53.899 \\
Residual & 56519.082 & 487 & 237.475 & \\
Total & 82118.481 & 492 & & \\
\hline
\end{tabular}

a Predictors: (Constant), $\mathrm{X}_{21}, \mathrm{X}_{24}$

Dependent Variable: MT

From the regression coefficients it was established that the most important element is attitude towards method of teaching mathematics. There is need for teachers to support boys on difficulties they encounter during learning of mathematics (Munyao, 2003) as this may help them to perform better in KCSE examination.

\section{IMPLICATION}

This variation not withstanding; the overall performance in mathematics in Kisumu East district at a mean percentage of 34.06 is considered as below average and was rated as poor performance. This result is quite dismal hence wanting. If students could participate in activities related to Mathematics like technology which they depend on such as the internet, play stations, Face Book, Twitter and Google this might help to keep them interested in the fields of mathematics which might change their attitude to being positive hence improve on mathematics performance.

\section{RECOMMENDATIONS}

Based on the results, the study recommends that:

1. When selecting students to form 1, the school principals should consider performance in mathematics in KCPE since it was the most significant variable that had a higher positive correlation with performance amongst the other variables tested.

2. There is need to ensure that students attitudes is enhanced which in turn will improve their performance in Mathematics.

3. The same study should be carried out in Kisumu County instead of Kisumu District using Form 4 results from Kenya National Examination Council to establish the findings of the present study which used researcher made test.

4. The teachers of Mathematics should make subject concepts to be practical to help improve on understanding of mathematics hence improve on performance.

\section{REFERENCES}

[1] Ayodo, H. (2009). How to solve the Math Problem. East Africa Standard, Wed $15^{\text {th }}$ April 2009. Retrieved on $29^{\text {th }}$ Jan, 2010 from Media House.

[2] Barton, A. (1998). Feminist science education. New York: Teachers College Press.

[3] Borg, R. W., Gall, D.M \& Gall, P.J. (2007). Educational Research: An introduction. USA: Longman Publishers.

[4] Bloom, B.S.(1976). Taxonomy of Educational Objectives Handbook 1. The Cognitive domain, N.Y: David McKay Co INC. Retrieved on $27^{\text {th }} \quad$ November, 2010 from http://www.Nwlink.com/-donclark/hrd/bloom.html.

[5] Howes, E.V.(2002). Connecting girls and science, Constructivism feminism, and education reform . New York: Teachers college press. Retrieved on $26^{\text {th }}$ January, 2010 from http://web.

Knowledge.Org/epistem3/pro-pdf/09-bassy-joshua-asim.pdf.

[6] Kothari, C.R.(2004). Research Methodology, Methods and Techniques. New Delhi: WishwaPrakashan Publication

[7] Likert, R. (1932). Techniques for the Measurement of Attitude, New York: McGraw Hill.

[8] Mugenda, O.M. Mugenda, A.G.(2003). Research Methods Quantitative and Qualitative Approaches . Nairobi: ACTS Press.

[9] Mullis, I.V.S. (2000). TIMSS 1999 International Mathematics Report: Findings from IEA's repeat of the Third International Mathematics and Science Study at eighth grade, Chestnut Hill, M.A: Boston College.

[10] Munyao, I. W.(2003). An investigationInto the Methods Used by Teachers in Teaching Mathematics in selected schools in Amasinga Division, Machakos District.Unpublished M.Ed Thesis, Kenyatta University, Nairobi: Kenya.

[11] Njoroge, K.N.(2004). Math still hard nut to crack in the East African Standard. Retrieved on $2^{\text {nd }}$ March , 2004 from Media House.

[12] Odhiambo, H. (2002). Education Reforms. Daily Nation February $26^{\text {th }}$, 2000. Nairobi APublication of Nation Media Group.

[13] Osaki, K.M.(2005). Forum for African Women Educationists (FAWE) SMT activists from 2005-2008. Framework for Data Base creation, gender responsive pedagogyscience camp design and movement in the IGSATA program, FAWE: Nairobi. Retrieved on $23^{\text {rd }}$ January, 2010 from http://docs, google.com.

[14] Ramani, K. (2004). Fifty Thousand Score Varsity Entry Marks. In East Africa Standard March $2^{\text {nd }} 2004$.

[15] Republic of Kenya(1999). Totally Integrated Quality Education and Training: Report of the Presidential Enquiry in Evaluation System of Kenya. Nairobi: Government Printer.

[16] Sinnes, A.T.(2005). Approaches to Gender equity in science education Two initiatives in sub-saharaAfrican seen through a lens derived from feminist critique of science. Oslo: Unipub. Retrieved on 23rdJanuary, 2010 from http://www.lls.uio.no/forkning/doktorarhand.linger/docs/Astridsinne Avhandling feminist critique of science. Oslo: Unipub.Pdf

[17] Siringi, S. (2010). Girls still losing out in education. In the Daily Nation, Nairobi, March $3^{\text {rd }}, 2010$.

[18] Weidmann, D. \&Humprey, S. (2002). Students Attitude and Perceptive involving Mathematics in schools.Journal of Educational Psychology, 74(30), 234-256. Retrieved on $29^{\text {th }}$ March,2010 from http://www.allacademic.com/meta/p11175-in... 